РОЗДІЛ 6. ТЕОРІЯ І МЕТОДИКА ВИХОВАННЯ

\author{
ОГЛЯД МОДЕЛЕЙ, ПРИНЦИПІВ, ФОРМ І МЕТОДІВ \\ ДИСТАНЦІЙНОГО НАВЧАННЯ
}

\title{
E-LEARNING MODELS, PRINCIPLES, FORMS AND METHODS OVERVIEW
}

УдК 37.211 .24

DOI https://doi.org/10.32843/2663-

6085/2020/30-2.25

\section{Гаврилюк Н.М.,}

канд. пед. наук,

доцент кафедри іноземної фрілології та перекладу

Вінницького торговельно-економічного інституту

Київського національного торговельноекономічного університету
Статтю присвячено найактуальнішій проблемі сьогодення - введенню в навчальновиховний процес дистанційного навчання як невіддільного елемента електронної педагогіки. Виклики сьогодення свідчать про те, що лише умови та обставини життя створюють необхідні передумови для виникнення та стрімкого впровадження дистанційноі освіти. Відпрацьовується та вдосконалюється методика організації дистанційного навчання. Акцентується увага на відведенні першочергової ролі дистаниійному навчанню в умовах пандемії.

Основна увага зосереджується на дидактичних принципах електронної педагогіки. Зокрема, розкриваються сутність принципів. Принцип інтерактивності, або діалогової взаємодії, є головним показником дидактичної ефективності електронної системи навчання.

Принцип створення дружнього середовища забезпечує можливість здійснення онлайннавчання та приводить до усунення психологічних бар'єрів. Принцип адаптивності $\epsilon$ виявом диференційованого підходу до навчання. Принцип особистісно-опосередкованої взаємодії спонукає до розвитку креативних здібностей студентів. Принцип відкритості комунікативного простору сприяє створенню навчального середовища за допомогою інтерактивних занять.

На основі аналізу психолого-педагогічної літератури описуються моделі дистанчійного навчання, запропоновані сучасними дослідниками. Змішана модель - інтеграція очних і дистанційних форм навчання. Викладач вищого навчального закладу планує майбутню модель навчання, створює інсрормаційно-предметне середовище з конкретного предмета та визначає, які види діяльності відбуватимуться дистанчійно з безпосередньою участю викладача. Мережеве навчання використовують в умовах, коли неможливо організувати очне чи заочне навчання. Така форма поширена серед людей, які працюють $і$ паралельно навчаються, для самостійного вивчення певних курсів.

Описано форми та методи здійснення дистанційного навчання. Висвітлюється дистанційне навчання як перспективна форма організації навчання, у якій студент виступає активним суб'єктом навчання. Описуються традиційні форми подачі інформації.
Ключові слова: дистанційне навчання, принципи дистанційного навчання, електронна педагогіка, практичні методи навчання, суб'єкт навчання.

The article is devoted to the most pressing problem of today - the introduction of distance learning in the educational process as an integral element of e-pedagogy. Today's challenges show that only the conditions and circumstances of life create the necessary preconditions for the emergence and rapid introduction of distance education. The method of organizing distance learning is being developed and improved. Emphasis is placed on assigning a primary role to distance learning in a pandemic.

The main focus is on the didactic principles of electronic pedagogy. In particular, the essence of the principles is revealed. The principle of interactivity or dialogue is the main indicator of the didactic effectiveness of the e-learning system.

The principle of creating a friendly environment provides the opportunity for online learning and leads to the removal of psychological barriers. The principle of adaptability is a manifestation of a differentiated approach to learning. The principle of personality-mediated interaction encourages the development of creative abilities of students. The principle of openness of the communicative space contributes to the creation of a learning environment through interactive classes.

Based on the analysis of psychological and pedagogical literature, the models of distance learning proposed by modern researchers are described. Mixed model - integration of full-time and distance learning. The teacher of the higher educational institution plans the future model of education, creates the information-subject environment on a concrete subject and defines what kinds of activity will take place remotely with direct participation of the teacher. Online learning is used in conditions when it is impossible to organize full-time or part-time learning. This form is common among people who work and study in parallel, for self-study of certain courses.

Forms and methods of distance learning are described. Distance learning is highlighted as a promising form of learning organization in which the student is an active subject of learning. Traditional forms of presenting information are described.

Key words: distance learning, principles of distance learning, e-pedagogy, practical teaching methods, subject of study.
Постановка проблеми в загальному вигляді. Виклики часу змушують освітян стрімко діяти і коректувати фрорми навчання, змінювати контент та пропонувати найбільш сприятливі умови для навчання студентів. 3 огляду на неможливість відвідувати вищі навчальні заклади все більшого оберту набирає впровадження дистанційної освіти. У вищих навчальних закладах до введення карантинних заходів існували очна та заочна фформи навчання, які мали свої плюси та мінуси. Боротьба 3 пандемією сприяла виникненню потреби в дистанційній фрормі навчання, 
яка вдало впроваджується в навчально-виховний процес у фрормі заздалегідь продуманих і розроблених курсів, наявності відповідного комп'ютерного забезпечення.

Якщо раніше вважалось, що для вдалого впровадження дистанційного навчання потрібні спеціально розроблені курси, належне технічне забезпечення, підготовлені фрахівці та ефективна методика навчання, то виклики сьогодення свідчать про те, що лише умови та обставини життя створюють необхідні передумови для виникнення та стрімкого впровадження дистанційної освіти. Бачимо, що всі навчальні заклади вдало застосовують форми дистанційного навчання. Відпрацьовується та вдосконалюється методика організації дистанційного навчання. Якщо раніше дистанційному навчанню відводилась другорядна роль у орормі, наприклад, екстернату або заочної фрорми навчання, то першочерговість дистанційної освіти нині не викликає сумніву. Ба більше, дистанційна форма поступово заміняє змішане навчання, тобто традиційне з елементами дистанційного.

Мета статті - проаналізувати різні моделі дистанційного навчання, які відповідають потребам і реаліям сучасної української освіти, та описати його форми та методи.

Аналіз останніх досліджень і публікацій доводить збільшений інтерес вітчизняних та зарубіжних науковців до питань розвитку дистанційної освіти. Досліджено напрями підвищення ефективності навчання 3 використанням інформаційних технологій (В. Биков, Р. Гуревич, М. Кадемія, Д. Опеншоу, Н. Тверезовська, І. Хорев, М. Жалдак, Ю. Жук); концептуальні педагогічні положення про дистанційне навчання (О. Андрєєв, Г. Козлакова, І. Козубовська, В. Олійник, Є. Полат, П. Стефаненко, А. Хуторський) тощо.

Виклад основного матеріалу. Сучасні класичні фрорми навчання не завжди задовольняють сучасні вимоги до здійснення освітнього процесу, оскільки деякі класичні елементи є вже застарілими, наприклад:

- навчання у вищому навчальному закладі як засіб здобуття знань на все життя;

- домінантна позиція педагога в освітньому процесі;

- подібна структура навчальних дисциплін та фрорм організації навчального процесу з акцентом на головній ролі аудиторних занять;

- книга - основний засіб отримання інформації.

Актуальності набувають поступово нові дидактичні принципи електронної педагогіки, а звідси і дистанційної освіти: інтерактивність, наявність дружнього середовища, адаптивність, особистісно-опосередкована взаємодія, відкритість комунікативного простору тощо [2, с. 15].

Розкриємо зміст деяких принципів електронного навчання. Принцип інтерактивності або діалогової взаємодії. Принцип реалізується в режимі роботи «студент - електронний засіб». В умовах електронного навчання активними є також електронні засоби, а не лише студенти. Електронні засоби і студенти $є$ рівними партнерами в навчанні. Інтерактивна взаємодія сприяє виникненню більшого інтересу студентів до навчання. Традиційні технічні засоби навчання мають лише прямий зв'язок, а засоби електронного навчання мають зворотний зв'язок. Саме цей принцип $€$ головним показником дидактичної ефективності електронної системи навчання.

Принцип створення дружнього середовища. Забезпечення можливості здійснення онлайннавчання приводить до усунення психологічних бар'єрів (страх спілкування, страх перед отриманням поразки, невдачі, страх перед відповідальністю). Тому дружня атмоссрера, як ніщо інше, допомагає перебороти саме психологічні «ступори» між студентом і комп'ютерними програмами, що заважають просуватися в навчанні та досягати успіху).

Дружній зовнішній вигляд навчальної програми сприяє:

- варіюванню режиму роботи, темпів роботи;

- надійності і простоті в роботі;

- допомозі студентам у фрормі негайного зворотного зв'язку;

- створенню позитивного настрою студентів;

- забезпеченню комфрортного спілкування 3 електронними засобами;

- забезпеченню зручного користування довідками та додатковою інфрормацією [2, с. 17].

Принцип адаптивності є проявом диференційованого підходу до навчання. Йдеться про індивідуальний спосіб передачі та темп засвоєння матеріалу, рівень складності тощо. Адаптивність електронних засобів навчання можна представити початковим тестуванням, поточним контролем результатів навчального процесу, урахуванням психолого-педагогічних особливостей (тривалість, темп, рівень складності). Адаптивність електронних засобів навчання в підготовці викладача до заняття проявляється в адаптації навчальних матеріалів до різних вікових категорій та до різних рівнів знань студентів. Адаптивність дає можливість змінювати бази даних навчальних програм, створювати власні навчальні програми відповідно до контингенту студентів.

Принцип особистісно-опосередкованої взаємодії [2, с. 18]. Переваги електронного або дистанційного навчання найбільш ефективно відображаються в принципі особистісно-опосередкованої взаємодії. Лише в спілкуванні можливо відстежити динаміку змін у процесі розвитку студентів, здійснювати аналіз творчої діяльності студентів, спонукати до розвитку креативних здібностей студентів тощо.

Принцип відкритості комунікативного простору. Створення навчального середовища за допомогою 
інтерактивних занять сприяє відкритості комунікативного простору, що дає можливість для зворотного зв'язку у фрормі рекомендацій щодо розвитку освітнього продукту. Використання графріки, кольору, спеціальних ефектів дає змогу розвивати індивідуальний творчий підхід до тих, хто залучений до процесу навчання дистанційно [2, с. 18].

Моделі дистанційного навчання. Наведімо приклад моделей дистанційного навчання. Змішана модель - інтеграція очних і дистанційних фрорм навчання. На думку дослідників, це найбільш перспективна модель. Викладач вищого навчального закладу планує майбутню модель навчання, створює інфрормаційно-предметне середовище 3 конкретного предмета та визначає, які види діяльності відбуватимуться дистанційно з безпосередньою участю викладача (оглядові лекції, семінарські й практичні заняття, заліки, іспити, захисти курсових, бакалаврських, магістерських робіт). Самостійне виконання певних видів робіт організовується дистанційно. Така фрорма навчання, з одного боку, спонукатиме до самостійної навчальної діяльності студента, з іншого - викладач постійно заохочує, допомагає, власним прикладом надихає і моніторить процес навчання та корегує процес залежно від можливостей і потреб кожного студента.

Сучасні науковці виокремлюють так зване мережеве навчання - це навчання, опосередковане Інтернетом. Цю модель використовують в умовах, коли неможливо організувати очне чи заочне навчання. Така фрорма поширена серед людей, які працюють і паралельно навчаються, для самостійного вивчення певних курсів. В. Кухаренко пропонує трирівневу систему введення дистанційного навчання: на першому етапі студенти вивчатимуть дисципліни з часто повторюваними завданнями, відповіді яких визначено; на другому - викладач взаємодіє зі студентом, спрямовує його навчання; на третьому рівні навчальний процес проводять провідні вчені в конкретних галузях із використанням сучасних засобів комунікації [3, с. 220]. I ще одна модель - це поєднання мережевого навчання та кейстехнологій. Така модель передбачає використання всесвітньої мережі та друкованої навчальної літератури (підручників, посібників, методичних вказівок).

Інтерактивне телебачення, відеоконференції $€$ моделлю, у якій навчання можливе лише 3 використанням телевізійного обладнання та відеокамер.

Р. Горбатюк визначив характеристики моделі дистанційної фрорми навчання. Вона має містити такі компоненти, що безпосередньо впливають на якість навчального процесу; модель повинна мати структуру, яка легко діагностується й контролюється на всіх стадіях її реалізації; модель має забезпечувати не тільки контроль за освітнім процесом, а й можливість його коригувати [1, с. 68].
Ще одна модель дистанційної освіти, розроблена В. Тверезовським і Н. Луковою-Чуйко, охоплює такі елементи, як: відкрите навчання, комп'ютерне навчання, активне спілкування між викладачами і студентами із використанням сучасних фртелекомунікацій [5, с. 215].

Форми дистанційного навчання. Формування компетенцій студентів під час дистанційного навчання знаходить своє відображення в організаційних фрормах (список наводить С. Щенниковий): вебінар, виконання контрольних робіт, відеоконференція, віртуальна консультація, віртуальний тьюторіал, груповий захист проєктів, ділова гра, іспит, індивідуальний захист проєктів, консультація, конференція, коучинг, круговий зворотний зв'язок, лабораторна робота, лекція, майстер-клас, наставництво, недільна школа, освітнє змагання, освітня експедиція, передача повноважень, практичне заняття, презентація, проєктно-аналітична сесія, робота 3 кейсами, робота над проєктом, ротація, самостійна робота, семінар (конореренція): офрлай або онлайн, стажування або виробнича практика, тьюторіал, тренінг, участь у проєктах.

О. Андаєв виокремлює також такі фрорми занять. Вважаємо, що ці фрорми вдало можна застосувати під час дистанційного навчання:

- лекції (аудіо-, відео-, слайд-лекція, текстова лекція);

- консультації (індивідуальні, групові, електронною поштою);

- семінари (аудіоконференція, відеоконференція);

- лабораторно-практичні заняття;

- курсові проєкти (групові, індивідуальні, дослідницькі, творчі, інфрормаційні);

- індивідуальні (домашні) завдання (есе, ресрерати, завдання тощо);

- тестування;

- іспити, заліки;

- ігрові види занять;

- ситуаційні практикуми (кейсові завдання);

- навчальні науково-дослідні роботи;

- екскурсії та майстер-класи;

- навчальне електронне портфоліо.

Поступово змінюються і фрорми роботи, що пов'язано з введенням дистанційного навчання. Йдеться про форуми, чати, блоги, аудіо- та відеоконореренції, ділові ігри, комп'ютерні ігри, спільне проєктування і редагування ресурсів, створення і зберігання посилань на навчальні ресурси, участь у проєктах мережевих спільнот, інтерактивний переклад, прив'язання подій, процесів до координат, опитування, голосування, комп'ютерний контроль знань, умінь і навичок [2, с. 29].

Постає проблема необхідності глибшого аналізу методики проведення навчальних занять, наприклад відеоконференцій-лекцій. Лекція у 
форматі проведення відеоконференції базується на створенні презентаційного матеріалу, що повинно підкреслювати педагогічний вплив на слухачів. Використання презентацій допомагає:

- реалізувати принцип наочності;

- емоційно прикрасити пояснення навчального матеріалу;

- створити подачу навчального матеріалу для легшого сприйняття його студентами;

- моніторити роботу студентів під час подання лекцій у форматі інтерактивного режиму.

Важливо на слайдах демонструвати суть. Поширеними реченнями викладач коментує матеріал. Введення інформації має бути поетапним. У разі необхідності презентування на одному слайді великого об'єму інсрормації його варто подати поступово за допомогою анімації [2, с. 31].

Основне завдання слайдів полягає, на нашу думку, саме у приверненні уваги глядачів, адже кожні 5 хвилин треба застосовувати прийоми активізації роботи студентів:

- яскраві та цікаві приклади;

- постійна презентація матеріалу;

- підтримання періодично зворотного зв'язку в режимі: викладач ставить питання - студент надає відповідь.

Традиційні методи і форми подачі інформації вже заздалегідь спрямованні на передавання інформації. I завдання викладача в такій системі навчання полягає у відтворенні матеріалу з метою пояснення нового матеріалу. Для такої форми подачі матеріалу, як лекція, заклало фрундамент Середньовіччя. Саме тоді існували «пасивні» лекції. Твердження, що проголошував учитель, вважалися істинами, а слова - непорушними законами (латина - verba magistri - слова вчителя; magister dixit - вчитель сказав).

Для студентів Середньовіччя було досить лише слухати і запам'ятовувати. Цілком зрозуміло, що середньовічний підхід сьогодні застарів.

Конспектування лекцій - це пасивний процес, який уже віджив себе. Актуальності набувають інтерактивні лекції, які передбачають осмислене конспектування, йдеться мова про конспектування термінів і позицій, за якими в будь-який час можна відтворити зміст лекції.

Важливим питанням постає також проведення практичних і лабораторних занять у фрорматі дистанційного навчання.
Під час дистанційного навчання є можливим застосування таких способів організації практичних і лабораторних робіт із метою:

- запровадити доступ для студентів до необхідного устаткування лабораторних робіт;

- імітувати або моделювати процес на комп'ютерній моделі, створюючи віртуальні лабораторії тощо.

Варто зазначити, що актуальності набувають словесні, наочні та практичні методи навчання. До словесних методів відносимо такі: розповідь, пояснення, бесіди, лекції, дискусії, консультації у вигляді блогів, фрорумів, чатів, відеоконференцій. Наочні методи застосовуються у формі проведення відеолекцій із застосуванням інтерактивних карт, схем, діаграм, мультимедійної та інтерактивної дошки, грасрічного планшету [2, с. 36].

До практичних методів відносимо виконання вправ за допомогою інтерактивних карт, діаграм, схем, інтерактивних тестів, комп'ютерних тренажерів, віртуальних стимуляторів тощо.

Висновки. Для того щоб стати конкурентоспроможним фрахівцем, варто опанувати способи ефективного самостійного навчання, систематично працювати над підвищенням своєї квалісрікації. Дистанційна фрорма показала своє панівне становище поряд із рештою фрорм навчання, що сприяє організації самоосвіти та являє собою інструмент неперервного навчання протягом усього життя.

\section{БІБЛІОГРАФІЧНИЙ СПИСОК:}

1. Горбатюк Р., Романишена Л. Експериментальна модель дистанційного навчання майбутніх фрахівців у вищому навчальному закладі. Наукові записки. Серія: Педагогіка. 2016. № 2. С. 68-75.

2. Костікова І. Електронна педагогіка: монографрія. Харків : Смугаста типограсрія, 2015. 160 с.

3. Кухаренко В. Система дистанційного навчання університету. Теорія та методика навчання математики, фрізики, інфоорматики. Т. XIII (2015). Вип. 3 (37). С. 220-233.

4. Осаульчик О. Критерії, показники та рівні сформованості творчого потенціалу студентів. Вісник Житомирського державного університету імені Івана Франка. 2012. (61). С. 159-163.

5. Тверезовський В., Лукова-Чуйко Н. Інформаційні процеси у вищій школі та дистанційна освіта: на роздоріжжі. Теорія методики навчання математики, фрізики, інфрорматики. Т. XIII (2015). Вип. 3 (37). С. 215-219. 